\title{
Blast Cells Count Influences Bleeding Incidence in Acute Leukemia: Preliminary Study in South Kalimantan, Indonesia
}

\author{
Edward Kurnia Setiawan Limijadi ${ }^{1 *} \mathbb{D}$, Qintani Cantika Ismail ${ }^{2}$, Dwi Retnoningrum ${ }^{1}$, Wivina Riza Devi ${ }^{3}$, Anugrah Riansari $^{4}$, \\ Villa Cita ${ }^{5}$ iD \\ ${ }^{1}$ Department of Clinical Pathology, Faculty of Medicine, Diponegoro University, Semarang, Indonesia; ${ }^{2}$ Department of Bachelor \\ Degree, Faculty of Medicine, Diponegoro University, Semarang, Indonesia; ${ }^{3}$ Department of Clinical Pathology, Ulin Hospital, \\ Banjarmasin, South Kalimantan, Indonesia; ${ }^{4}$ Department of Parasitology, Faculty of Medicine, Diponegoro University, Semarang, \\ Indonesia; ${ }^{5}$ Postgraduate Program of Clinical Pathology, Faculty of Medicine, Diponegoro University, Semarang, Indonesia
}

Edited by: Ksenija Bogoeva-Kostovska Citation: Limijadi EKS, Ismail QC, Retnoningrum D, Devi WR, Riansari A, Cita V. Blast Cells Count Influences Bleeding Incidence in Acute Leukemia: Preliminary Study in South Kalimantan, Indonesia. Open Access Maced $J$ Med Sci. 2021 Aug 29; 9(B):900-902. https://doi.org/10.3889/oamjms.2021.6860 Keywords: Acute; Leukemia; Blast cell count; Bleeding Correspondence: Edward Kurnia Setiawan Limijadi, Diponegoro University Semarang, Central Java, University Semarang, Central Java, E-mail: edwardks 83862305904 Received: $17-\mathrm{Jul}-2021$ Revised: 17-Aug-202 Accepted: 19-Aug-2021
Copyright: ๑ 2021 Edward Kurnia Setiawan Limijadi, Qintani Cantika Ismail, Dwi Retnoningrum, Wivina Riza Devi, Anugrah Riansari, Villa Cita Funding: This research did not receive any financia Competing Interests: The authors have declared that competing interest exists -access article distributed Open Access: This is an opeative Commons AttributionNonCommercial 4.0 International License (CC BY-NC 4.0)

\begin{abstract}
BACKGROUND: Acute leukemia is a malignant disease involving hematopoietic tissue, characterized by abnormal blood cells in bone marrow or called blast cells. The most common complications of acute leukemia are bleeding. A high percentage of blasts have been reported to increase the risk of bleeding in acute leukemia.

AIM: Preliminary study was needed to investigate relationship between blast cells count and bleeding incidence in acute leukemia.

METHODS: A cross-sectional study with observational analytic in 38 adult subjects was conducted from November 2019 to May 2021 in Ulin Hospital, Banjarmasin, South Kalimantan. The data were taken from medical records of acute leukemia patients who met inclusion and exclusion criteria. Data analysis was using Fisher's exact test.

RESULTS: This study enrolled 17 men and 21 women. Blast cells count in peripheral with cutoff $<50 \%$ was $20(52.6 \%)$ and $\geq 50 \%$ was $18(47.4 \%)$ and otherwise in bone marrow. Both of women and men mostly have bleeding in acute leukemia, and bleeding incidence in women is higher than men. Bleeding condition was happened both in peripheral and bone marrow blast cells count with cutoff $<50 \%$ and $\geq 50 \%$. Significance of relationship between blast cells count and bleeding incidence was 0.669 .
\end{abstract}

CONCLUSION: There is no significant relationship between blast cells count and bleeding incidence in acute leukemia. Another parameters that could influence bleeding incidence need to be investigated in acute leukemia.

\section{Introduction}

Acute leukemia is a malignant disease characterized by the displacement of normal bone marrow components by abnormal blood cells or called blast cells [1]. Acute leukemia is divided into two types, namely, acute myeloid leukemia (AML) that attacks myeloid cells and acute lymphoblastic leukemia that attacks lymphoid cells [2]. The American Cancer Society states the incidence of leukemia in the United States in 2020 reached 19,940 new cases occurring in AML with a mortality rate of 11,180 cases due to $A M L$ [3]. The clinical manifestation features in acute leukemia include bone marrow failure in forming normal blood cells because of the accumulated blast also accompanied by infiltration of organs [4]. Blast cell presentations more than $30 \%$ in the bone marrow are found during clinical examination of acute leukemia [5].

One of the most common complications of acute leukemia is bleeding caused by various hemostatic disorders [1]. A high percentage of blasts have been reported to increase the risk of bleeding in acute leukemia, which is one of the complications of acute leukemia which can increase the risk of death [6]. Mucosal bleeding or bleeding under the skin is common manifestations of acute leukemia and is usually associated with platelet deficiency [7]. The study of relationship between blast count and bleeding incidence is still limited, especially in Indonesia. This is preliminary study to investigate their relationship in South Kalimantan. This area has many factories that contribute air pollution as one of the antigens to promote acute leukemia.

\section{Methods}

An observational study with cross-sectional approach was conducted in Ulin Hospital, Banjarmasin, South Kalimantan, from November 2019 to May 2021. 
The subjects of the study were 38 acute leukemia patients who met inclusion and exclusion criteria by consecutive sampling. The inclusion criteria were $>15$ years old, $1^{\text {st }}$ time diagnosis of leukemia, men and women, normal body temperature, steroid free, menstruation was normal according to age for women, drug free causes coagulation/anticoagulant abnormalities, while the exclusion criteria were patients with history or were suffering autoimmune disease, coronary heart disease and stroke or other blood vessel abnormalities, kidney abnormalities, liver abnormalities, and malignancies other than leukemia and trauma.

Data were taken from medical records in Ulin Hospital, including name, age, sex, activity, current symptoms, history of previous hematological diseases, and results of laboratory data (complete blood count and bone marrow aspiration). Complete blood count was performed by Sysmex XN-1000. Bone marrow aspiration was done and interpretated by clinical pathologist. Data analysis was performed by statistical program computer. Fisher's exact test was conducted to examine the relationship between the number of blast cells with the incidence of bleeding in acute leukemia. The result of statistical test is significant if $p<0.05$ was considered. Ethical clearance was obtained from the Medical and Health Research Ethics Commission of the Dr. Kariadi Hospital Semarang, number 417/EC/KEPK-RSDK/2019.

Table 1: Characteristics of subjects

\begin{tabular}{|c|c|c|c|}
\hline Variable & $\mathrm{F}$ & $\%$ & Median (min-max) \\
\hline Age & & & $34.5(16-67)$ \\
\hline Adolescence (13-18 years) & 7 & & \\
\hline Adult (19-59 years) & 26 & & \\
\hline Senior adult ( 60 years and above) & 5 & & \\
\hline \multicolumn{4}{|l|}{ Gender } \\
\hline Men & 17 & 44.7 & \\
\hline Women & 21 & 55.3 & \\
\hline \multicolumn{4}{|l|}{ Activity } \\
\hline Housewife & 12 & 31.6 & \\
\hline Farmer & 7 & 18.4 & \\
\hline College student & 4 & 10.6 & \\
\hline Civil servants & 6 & 15.8 & \\
\hline Construction laborer & 1 & 2.6 & \\
\hline Student & 7 & 18.4 & \\
\hline Retirement & 1 & 2.6 & \\
\hline Weight (kg) & & & $54(38-68)$ \\
\hline Height (cm) & & & $160(150-173)$ \\
\hline Hemoglobin (g/dL) & & & $8.6(3.3-13.2)$ \\
\hline Hematocrit (\%) & & & $26.5(10.7-42.0)$ \\
\hline Erythrocytes $\left(\times 10^{6} / \mu \mathrm{L}\right)$ & & & $3.00(1.09-5.22)$ \\
\hline MCV (fl) & & & $87(79.0-105)$ \\
\hline $\mathrm{MCH}(\mathrm{pg})$ & & & $29(25-34)$ \\
\hline $\mathrm{MCHC}(\mathrm{g} / \mathrm{dL})$ & & & $33(30-37)$ \\
\hline Leukocyte count (cells/ $\mu \mathrm{L}$ ) & & & $16,950(351-118,200)$ \\
\hline Platelet count (cells $/ \mu \mathrm{L})$ & & & $43,500(6000-256,000)$ \\
\hline \multicolumn{4}{|l|}{ Peripheral blast cells count } \\
\hline$<50 \%$ & 20 & 52.6 & \\
\hline$\geq 50 \%$ & 18 & 47.4 & \\
\hline \multicolumn{4}{|l|}{ Bone marrow blast cells count } \\
\hline$<50 \%$ & 18 & 47.4 & \\
\hline$\geq 50 \%$ & 20 & 52.6 & \\
\hline
\end{tabular}

F: Frequency, Min: Lowest value, max: Highest value.

\section{Results}

The characteristic data of subjects are shown in Table 1. Hematology profile showed that some subjects were normocytic normochromic anemia, leukopenia, leukocytosis, thrombocytopenia, and also thrombocytosis.

The cutoff blast cells count in this study is $<50 \%$ and $\geq 50 \%$. It was found that there were 18 subjects $(47.4 \%)$ who had bone marrow blast cells count $<50 \%$ and 20 subjects $(52.6 \%)$ who had number of bone marrow blast cells count $>50 \%$. Peripheral blast cells count showed otherwise. There were 20 subjects (52.6\%) who had peripheral blast cells count $<50 \%$ and 18 subjects $(47.4 \%)$ who had peripheral blast cells count $>50 \%$.

Table 2: Bleeding incidence related to sex

\begin{tabular}{llll}
\hline Bleeding & Sex (person) & Total \\
\cline { 2 - 3 } & Men & Women & \\
\hline Yes & 9 & 8 & 17 \\
No & 8 & 13 & 21 \\
Total & 17 & 21 & 38 \\
\hline
\end{tabular}

Table 2 shows that both of women and men mostly have bleeding in acute leukemia, and bleeding incidence in women is higher than men. Table 3 shows that bone marrow blast cells count with cutoff $\geq 50 \%$ has slightly more bleeding incidence, while in peripheral blast cell count with cutoff $\geq 50 \%$ has slightly lesser bleeding incidence. Bleeding condition could be happened in acute leukemia with low blast cells count, even high blast cells count.

Table 3: Bleeding incidence related to peripheral and bone marrow blast count

\begin{tabular}{|c|c|c|c|c|c|c|}
\hline \multirow[t]{2}{*}{ Bleeding } & \multicolumn{2}{|c|}{ Peripheral blast cells count } & \multirow[t]{2}{*}{ Total } & \multicolumn{2}{|c|}{ Bone marrow blast cells count } & \multirow[t]{2}{*}{ Total } \\
\hline & $<50 \%$ & $\geq 50 \%$ & & $<50 \%$ & $\geq 50 \%$ & \\
\hline Yes & 8 & 9 & 17 & 8 & 9 & 17 \\
\hline No & 12 & 9 & 21 & 10 & 11 & 21 \\
\hline Total & 20 & 18 & 38 & 18 & 20 & 38 \\
\hline
\end{tabular}

Data were analyzed by Fisher's exact test to examine the relationship between blast cells count and bleeding incidence in acute leukemia. Based on the Fisher's exact test, the result showed that there was no significant correlation between blast cells count and bleeding incidence in acute leukemia, as shown in Table 4.

\section{Table 4: Fisher's exact test results}

\begin{tabular}{ll}
\hline Variable & Bleeding incidence \\
\cline { 2 - 2 } & $\mathrm{p}$ \\
\hline Blast cells count & 0.669 \\
\hline
\end{tabular}

\section{Discussion}

The result of Fisher's test between blast cells count and bleeding incidence showed that there was no significant correlation. The study has same result with Kim et al. (2006) and Balmages et al. (2018) found that there were no significant relationship blast cells count and bleeding incidence in acute leukemia [6], [8]. 
An unsignificant relationship between blast cells count and bleeding incidence can be caused by several factors. One of them is state of cytopenia. The results showed that patients had decreased levels of hemoglobin, hematocrit, erythrocytes, and platelets. In patients with AML, there is a blockade of maturity that causes the process of differentiation of myeloid series cells stops in young cells (blast), resulting in accumulation of blast cells in the bone marrow [9]. Thrombocytopenia is a major risk factor for bleeding in acute leukemia [10]. Webert (2006) found that there was a relationship between bleeding incidence and thrombocytopenia in acute leukemia patient that more influence the bleeding state [11].

Another factor is age, acute leukemia can affect all ages [12]. The incidence of AML increases with age and this disease is more common in men than women that reversely happened in this study. Gender can also affect the incidence of bleeding in patients with acute leukemia. Kelton et al. (2011) found that sex was associated with differences in sensitivity in terms of platelet aggregation between men and women [13]. The agregation of thrombocytes in male is easier to happen than female. Bleeding incidence that occurs in female patients can be associated with the use of oral contraceptives and hormone replacement therapy in women [14]. In addition, female sex hormones can increase the risk of coagulopathy in acute leukemia [6].

This study has analyzed blast cells count only. Based on theory, bleeding could be occurred in thrombocytopenia than high blast cell count. Another parameters such as hemostasis parameters and biomolecular parameters related to leukemia cells also host cells were not examined in this preliminary study. Future studies need to perform those parameters correlate with bleeding incidence.

\section{Conclusion}

There is no significant relationship between blast cells count and the bleeding incidence in acute leukemia. Another parameters that could be influenced bleeding incidence need to be investigated in acute leukemia.

\section{Acknowledgment}

The author would like to thank the laboratory technicians, nurses, and doctors in Ulin Hospital, Banjarmasin, South Kalimantan that they have assisted in sampling collection, patient management, and the examination of the laboratory parameters in this study.

\section{References}

1. Dia Rofinda Z. Kelainan hemostasis pada leukemia. J Kesehat Andalas. 2012;1(2):68-74. https://doi.org/10.25077/jka.v1i2.40

2. Lagunas-Rangel FA, Chavez-Valencia V, Gomez-Guijosa MA, Cortes-Penagos C. Acute myeloid leukemia genetic alterations and their clinical prognosis. Int $\mathrm{J}$ Hematol Stem Cell Res. 2017;11(4):329-39

PMid:29340131

3. Hunger SP, Mullighan CG. Acute lymphoblastic leukemia in children. N Engl J Med. 2015;373(16):1541-52.

PMid:26465987

4. Saultz JN, Garzon R. Acute myeloid leukemia: A concise review. J Clin Med. 2016;5(3):33.

PMid:26959069

5. Angelescu S, Berbec NM, Colita A, Barbu D, Lupu AR. Value of multifaced approach diagnosis and classification of acute leukemias. Maedica (Buchar). 2012;7(3):254-60.

PMid:23401730

6. Kim H, Lee JH, Choi SJ. Risk score model for fatal intracrania hemorrhage in acute leukemia. Leukemia. 2006;20(5):770-6. https://doi.org/10.1038/sj.leu.2404148

PMid:16525500

7. Sellar RS, Fraser L,Khwaja A, Gale RE, Marafioti T, Akarca A. Cell cycle status in AML blast cells from peripheral blood, bone marrow aspirates and trephines and implications for biological studies and treatment. $\mathrm{Br} J$ Haematol. 2016;174(2):275-9. https://doi.org/10.1111/bjh.14055

PMid:27061724

8. Balmages A, Dinglasan J, Osborn MB. Severe intracranial hemorrhage at initial presentation of acute myelogenous leukemia. Clin Pract Cases Emerg Med. 2018;2(3):203-6. https://doi.org/10.5811/cpcem.2018.4.37881

PMid:30083633

9. O'Donnell MR, Appelbaum FR, Baer MR, Byrd JC, Coutre SE, Damon LE, et al. Acute myeloid leukemia: Clinical practice guidelines in oncology. J Natl Compr Cancer Netw. 2006;4(1):1636. https://doi.org/10.6004/jnccn.2006.0004 PMid:31200351

10. Psaila B, Bussel JB. Differences in platelet function in patients with acute myeloid leukaemia and myelodysplasia compare. J Thromb Haemost. 2011;9(11):2302-10.

PMid:21920014

11. Webert KE. The risk of bleeding in thrombocytopenic patients with acute myeloid leukemia. Haematologica. 2006;9:1530-7.

PMid:17043016

12. Estey EH. Acute myeloid leukemia: 2019 update on risk-stratification and management. Am J Hematol. 2018;93(10):1267-91. https://doi.org/10.1002/ajh.25214 PMid:30328165

13. Kelton JG, Powers P, Julian J, Boland V, Carter CJ, Gent M, et al. Sex related differences in platelet aggregation: Influence of the hematocrit. Blood J Am Soc Hematol. 2011;56(1):38-41. https://doi.org/10.1182/blood.v56.1.38.38

PMid:7388180

14. Bodur S, Ayaz Y, Topallar F, Erdem G, Gün I. Severe uterine hemorrhage as first manifestation of acute leukemia. Eastern $J$ Med. 2011;16(1):62-5. 